\title{
REDD plus readiness implications for Sri Lanka in terms of reducing deforestation
}

\author{
Eskil Mattsson, U Martin Persson, Madelene Ostwald and S P Nissanka
}

\section{Linköping University Post Print}

N.B.: When citing this work, cite the original article.

Original Publication:

Eskil Mattsson, U Martin Persson, Madelene Ostwald and S P Nissanka, REDD plus readiness implications for Sri Lanka in terms of reducing deforestation, 2012, Journal of Environmental Management, (100), 29-40.

http://dx.doi.org/10.1016/j.jenvman.2012.01.018

Copyright: Elsevier

http://www.elsevier.com/

Postprint available at: Linköping University Electronic Press

http://urn.kb.se/resolve?urn=urn:nbn:se:liu:diva-76934 


\title{
REDD+ readiness implications for Sri Lanka in terms of reducing deforestation
}

\author{
Eskil Mattsson ${ }^{\mathrm{a},{ }^{*}}$, U. Martin Persson ${ }^{\mathrm{b}, \mathrm{c}}$, Madelene Ostwald ${ }^{\mathrm{c}, \mathrm{d}}$ and S.P. Nissanka ${ }^{\mathrm{e}}$ \\ ${ }^{a}$ Department of Earth Sciences, University of Gothenburg, Sweden. Box 460, 40530 Göteborg, \\ Sweden.Email: eskil@gvc.gu.se Tel:+46(0)31 786 2828, Fax:+46(0)31 7861986 \\ ${ }^{\mathrm{b}}$ Gothenburg Centre of Globalization \& Development, Department of Economics, University of \\ Gothenburg, Box 640, 40530 Göteborg, Sweden.Email: martin.persson@economics.gu.se
}

${ }^{\mathrm{c}}$ Division of Physical Resource Theory, Department of Energy and Environment, Chalmers University of Technology, 41296 Göteborg, Sweden.Email: madelene.ostwald@chalmers.gu.se

${ }^{\mathrm{d}}$ Centre for Climate Science and Policy Research, Linköping University, 60174 Norrköping, Sweden. Email: madelene.ostwald@liu.se

${ }^{e}$ Department of Crop Science, Faculty of Agriculture, University of Peradeniya, Peradeniya, Sri Lanka.Email:spn@pdn.ac.lk

*Corresponding author

\section{Abstract}

Any system to compensate countries for reduced emissions from deforestation and forest degradation (REDD+) requires a historical reference level against which future performance can be measured. Here we examine the possibilities Sri Lanka, a small forest country with limited data on forest carbon stocks, has to get ready for REDD+. We construct a historical reference level using available forest inventory data combined with updated 2008 and 2009 in situ carbon density data for Sri Lankan forests. Furthermore, we use a combination of qualitative and quantitative data to attribute the clearing of Sri Lankan forests in the latest years for which national forest inventory data are available, 19921996, to various proximate drivers and to estimate the opportunity cost of forest conservation. We estimate that baseline deforestation emissions in Sri Lanka amounted to $17 \mathrm{MtCO}_{2}$ year ${ }^{-1}$ in the 1992 1996 period, but conclude that it is challenging for Sri Lanka to produce a robust and accurate reference level due to the lack of nationally based inventories. We find that the majority of forest clearing $(87 \%)$ is due to small-scale, rainfed farming, with the two other major drivers being rice and tea cultivation. Further, Sri Lankan revenues from REDD+ participation could be substantial, but they are sensitive to REDD+ policy transaction cost, highly uncertain timber revenues, and particularly the carbon price paid for emission reductions. The latter needs to be higher than $\$ 5-10 / \mathrm{tCO}_{2}$ if there are to be substantial incentives for Sri Lanka to participate in REDD+. There is, however, a large gap in the knowledge of deforestation drivers that needs to be filled if Sri Lanka is to formulate an effective policy response to forest degradation in REDD+. For successful REDD+ implementation in Sri Lanka to happen, technological assistance, readiness assistance, and continued political momentum are crucial.

Keywords: REDD+, Deforestation, Forest inventories, Carbon stock, Sri Lanka, opportunity cost 


\section{Introduction}

In recent years, reducing emissions from deforestation and forest degradation, conservation, enhancement of forest carbon stocks and sustainable management of forests (REDD+) has been one of the key issues in international climate negotiations within the United Framework Convention on Climate Change (UNFCCC). As multilateral negotiations have progressed, interest among countries to prepare for hosting REDD+ projects and in testing the potential mechanism has increased significantly.

One REDD+ issue that will be tested in these initiatives is the development of national historical forest carbon reference levels ${ }^{1}$ (Griscom et al., 2009). Any system that intends to compensate countries for avoided deforestation requires a reference level for recent forest carbon stocks against which future performance can be measured. The choice of reference level will determine not only the effectiveness of REDD+ in terms of climate impact, but also the potential financial benefits to recipients of REDD+ funding and hence the incentives for tropical countries to participate in the scheme (Angelsen et al., 2009). Agreeing on a methodology for establishing national reference levels is therefore fundamental to any REDD+ system.

As international deliberations on REDD+ have proceeded, proposals for establishing national reference levels have become more advanced and numerous (e.g., Mollicone et al., 2007; Strassburg et al., 2009). Most such proposals deal with how to reward performance and create incentives for REDD+ actions to nations with different historical forest records, to deal with the facts that (1) using historical emission levels as a benchmark for future performance may be problematic, since the past may not perfectly foretell the future, ${ }^{2}$ and (2) historical reference levels may disadvantage nations with low deforestation rates, giving them little incentive to participate in a REDD+ system and hence may create leakage.

A global REDD+ mechanism will require broad country participation to avoid cross-country leakage, ensure equity and substantive emission reductions, thus also including smaller countries with various forest cover, deforestation rates and high biodiversity values (Miles, 2007; Strassburg et al., 2009). Countries that due to their size and their historical emissions level have contributed marginally to increased levels of greenhouse gases (GHG) in the atmosphere have received less attention in the REDD+ literature than the major players (Brazil, Indonesia, DR Congo). It will however be important to include smaller, low emission countries like Sri Lanka into a REDD+ system. In addition to the risk of creating leakage, the total deforestation in all low emission countries combined might produce and add significant emissions to the atmosphere without a REDD+ system. For equity concerns it is also justified to include Sri Lanka and similar countries to ensure distribution of possible REDD+ benefits.

The methodological guidance related to REDD+ adopted at Conference of the Parties (COP) 15 in Copenhagen (UNFCCC, 2009) states that "developing country Parties in establishing forest reference

\footnotetext{
${ }^{1}$ Reference levels are suggested to include all emissions and removals associated with REDD+ activities whereas reference emission levels are suggested to refer to emissions from deforestation and degradation only (UNFCCC,2011a). We hereafter use the term reference levels since no official definition is adopted within UNFCCC between the two terms (UNFCCC, 2011b).

${ }^{2}$ For example, for countries with high historical deforestation rates but low forest cover, historical reference levels may overestimate future deforestation, while for countries with low historical deforestation and high forest cover, the opposite holds (e.g., Angelsen et al., 2009).
} 
emission levels and forest reference levels should do so transparently taking into account historic data, and adjust for national circumstances", which was reiterated at COP 16 in Cancùn (UNFCCC, 2010). Even though credited REDD+ reference levels will ultimately be determined in a political setting through negotiations (Angelsen et al., 2009), regardless of the final modalities of this process, historical emission levels will likely serve as a natural starting point. Together with identifying proximate causes of forest carbon stock changes (i.e., deforestation, forest degradation, and regeneration), establishing historical reference levels is a thus fundamental activity in preparing for REDD+ (UNFCCC, 2009).

This paper offers an analysis of these aspects for Sri Lanka, a forest nation possessing limited forest status data, high mitigation potential in the national forestry sector and low overall contribution to emissions. Specifically, the objectives are to investigate the extent to which available data on forest cover and carbon stocks, changes in these, and drivers of these changes can be used to:

(1) create a historical reference level for carbon dioxide $\left(\mathrm{CO}_{2}\right)$ emissions from deforestation in Sri Lanka;

(2) identify proximate causes of deforestation in Sri Lanka and associated opportunity costs of forest conservation; and

(3) estimate the economic gains to Sri Lanka of becoming a REDD+ nation and the possible climate benefits that could be expected.

Based on the results of this analysis, we aim to identify crucial knowledge gaps to be filled if Sri Lanka is eventually to become part of a formal REDD+ system.

The data used in the carbon stock analysis come from national inventories used for reporting to the FAO Forest Resource Assessments (FRA) (FAO, 2005; FAO, 2010a) and from data we collected when conducting in situ forest inventories in Sri Lanka from 2008 to 2009. The historical carbon stock change approach has been used (Penman et al., 2003) covering the 1992-2010 period, adopting a Tier 2 approach $^{3}$ according to the IPCC Good Practice Guidance (GPG) (IPCC, 2006). For costs and earnings, we use a combination of qualitative and quantitative data to attribute the clearing of Sri Lankan forests in 1992-1996 to various proximate drivers and to estimate the opportunity cost of conservation. We focus here on the issue of deforestation rather than the full spectrum of possible REDD+ activities, as the former is the issue where negotiations and pilot activities have proceeded the furthest and where methodological challenges seems easiest to overcome.

This paper proceeds as follows: section 2 offers a brief background to the status of forests and forest protection in Sri Lanka, including the country's stance in REDD+ deliberations. Section 3 introduces the methodology used in estimating forest carbon stocks in Sri Lanka and presents a REDD+ baseline for Sri Lanka. Based on the carbon stock and reference level results, section 4 then proceeds to present estimates of the opportunity costs of forest conservation and the potential gains to Sri Lanka from participating in an international REDD+ scheme. In the light of these findings from the previous sections, section 5 concludes with a discussion on the challenges Sri Lanka faces in terms of getting ready for REDD+.

\footnotetext{
${ }^{3}$ The different tiers is a set of guidelines for estimating GHG inventories at different levels of quality, from Tier 1 (simplest to use; globally available data), to Tier 2 (nationally-derived data which allow for more precise estimates where changes in carbon stock are calculated), and Tier 3 (high resolution methods specific for each country and repeated through time) (IPCC, 2006).
} 


\section{Background on Sri Lankan forests and REDD+ activities}

Sri Lanka has a total land area of $65,610 \mathrm{~km}^{2}$ and an estimated population of 20.5 million (Department of Census and Statistics, 2010). GHG emission levels are low in both absolute and per capita terms, amounting to $26.1 \mathrm{MtCO}_{2} \mathrm{e}$ and $1.3 \mathrm{tCO}_{2} \mathrm{e}$, respectively, in 2005-excluding land use change (CAIT, 2010). Emissions from land use change and forestry constituted nearly $50 \%$ of national emissions in 1994. Although this proportion has decreased due to large increases in fossil fuel emissions, the mitigation potential in the forestry sector is still large relative to that in other sectors in the country. However, the rate and extent of land use change is not properly documented, according to the first Sri Lankan National Communication to UNFCCC (Government of Sri Lanka, 2000).

\subsection{Forests and forest area change in Sri Lanka}

Eight national categories of natural forests, defined according to elevation and rainfall, have been used historically for inventory purposes and are also adopted in this study (see Table 1). Lowland rainforest, sub-montane forest, and montane forest are found in the wet zone located in the southern and central parts of the island, while the dry zone is home to most dry monsoon forests, riverine dry forest, mangroves, and sparse forest (Fig. 1).

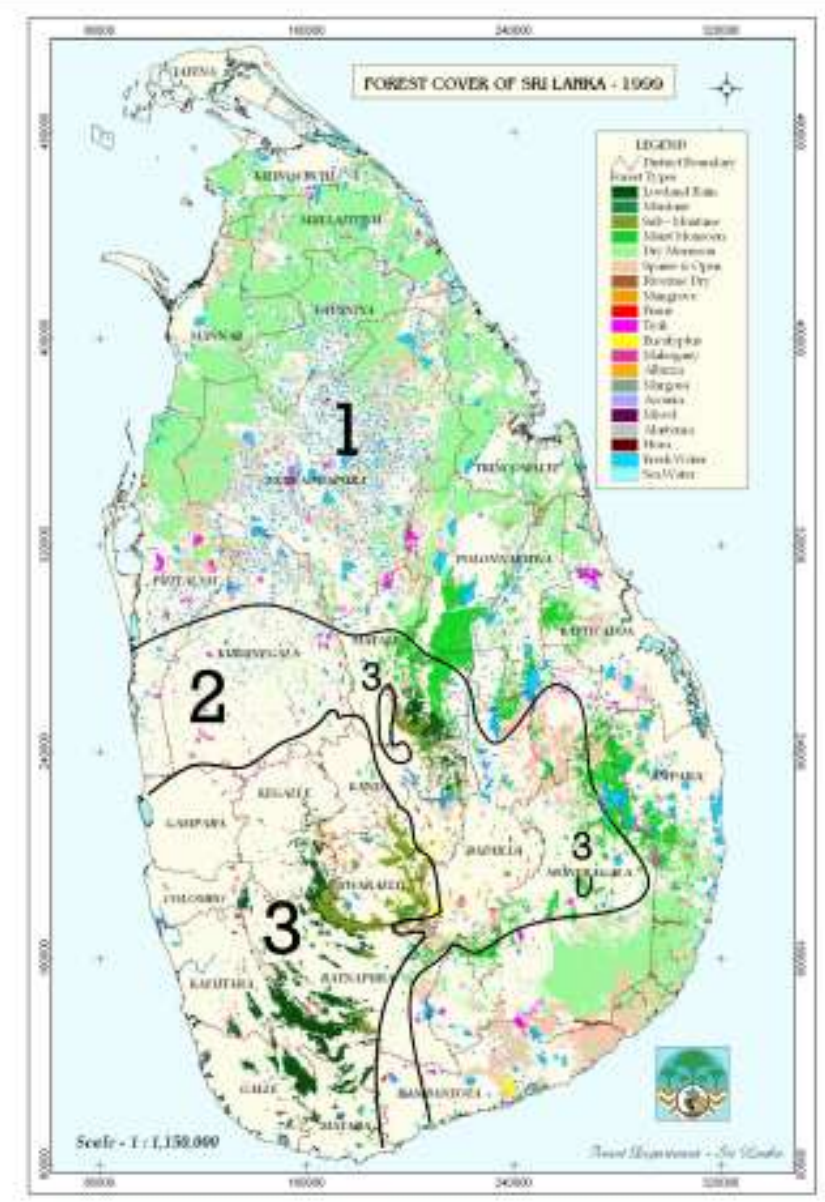

Fig. 1. Forest cover of Sri Lanka in 1999 and climatic zones. Area (1) indicates the dry zone, (2) the intermediate zone, and (3) the wet zone. Modified from GOSL (2000). 
Table 1. National forest classification and definitions (FAO, 2005) and trends in extent of natural forest cover for the eight natural forest categories in Sri Lanka, 1992-1996. Data are modified from Legg and Jewell (1995) and GOSL (2000).

\begin{tabular}{|c|c|c|c|c|c|}
\hline \multirow[t]{2}{*}{ National category } & \multirow[t]{2}{*}{ Definition } & \multicolumn{2}{|c|}{ Forest area (ha) } & \multicolumn{2}{|c|}{$\begin{array}{l}\text { Annual change, } \\
1992-1996\end{array}$} \\
\hline & & 1992 & 1996 & $(\%)$ & ha $\mathrm{yr}^{-1}$ \\
\hline $\begin{array}{l}\text { Closed-canopy } \\
\text { forests }\end{array}$ & $\begin{array}{l}\text { All forested land with canopy density of } 70 \% \\
\text { or above }\end{array}$ & & & & \\
\hline Montane & $\begin{array}{l}1500-2500 \text { m.a.s.l., annual rainfall } 2500-5000 \\
\text { mm, no dry months }\end{array}$ & 3108 & 3099 & -0.1 & -2 \\
\hline Sub-montane & $\begin{array}{l}1000-1500 \text { m.a.s.l., annual rainfall } 2500-5000 \\
\text { mm, no dry months }\end{array}$ & 68,839 & 65,792 & -1.1 & -762 \\
\hline $\begin{array}{l}\text { Lowland rainforest } \\
\text { (evergreen ) }\end{array}$ & $\begin{array}{l}0-1000 \text { m.a.s.l., annual rainfall } 2500-5000 \mathrm{~mm} \text {, } \\
\text { no dry months }\end{array}$ & 141,550 & 124,341 & -3.2 & -4302 \\
\hline $\begin{array}{l}\text { Moist monsoon forest } \\
\text { (evergreen) }\end{array}$ & $\begin{array}{l}\text { 0-1000 m.a.s.l., annual rainfall } 1900-2500 \mathrm{~mm} \text {, } \\
\text { fewer than } 3 \text { dry months }\end{array}$ & 243,863 & 221,977 & -2.3 & -5472 \\
\hline $\begin{array}{l}\text { Dry monsoon } \\
\text { (dry mixed } \\
\text { evergreen) }\end{array}$ & $\begin{array}{l}0-500 \text { m.a.s.l., annual rainfall } 1250-1900 \mathrm{~mm}, 4- \\
5 \text { dry months }\end{array}$ & $1,094,289$ & $1,027,544$ & -1.6 & $-16,886$ \\
\hline Mangrove forest & Area covered by mangrove vegetation & 22,534 & 18,352 & -5.0 & -1046 \\
\hline Riverine dry & Forests found along rivers and streams & 8688 & 9531 & +2.3 & +211 \\
\hline Open-canopy forests & $\begin{array}{l}\text { All forested land with canopy density of less } \\
\text { than } 70 \%\end{array}$ & & & & \\
\hline Sparse & & 463,848 & 471,583 & +0.4 & +1934 \\
\hline Total & & $2,046,719$ & $1,942,219$ & -1.3 & $-26,125$ \\
\hline
\end{tabular}

For many decades, Sri Lankan forests have been cleared both legally and illegally due to rapidly increasing demand for land for settlement schemes, economic purposes, timber production, and agricultural development and weak enforcement of land use policies (Gunatilake, 1998; Government of Sri Lanka, 2000; Bandaratillake and Sarath Fernando, 2003). As of 1997, approximately 14\% of the total land area was conserved. The management of conservation areas, however, is largely ineffective and suffers from insufficient scientific direction and weak enforcement (FAO, 1997) that results in forest-dependent people encroaching on the margins of forest reserves, partly because many boundaries have not been adequately demarcated (Bandaratillake and Sarath Fernando, 2003). The recently ended war between the government and the Liberation Tigers of Tamil Eelam (LTTE) also contributed to deforestation by increasing the demand for timber construction and displacing settlements (White, 2006; Suthakar and Bui, 2008). Natural forests covered almost the whole island a few centuries ago, and the closed-canopy forest cover has dwindled from $84 \%$ in 1884 to approximately 19\% in 2005 (Fig. 2) (Nanayakkara, 1996; FAO, 2005). As can be seen in Table 1, deforestation in 1992-1996 was most severe in riverine dry forest, lowland rainforest, and moist monsoon forest, whereas cover of mangrove and sparse forests has increased. 


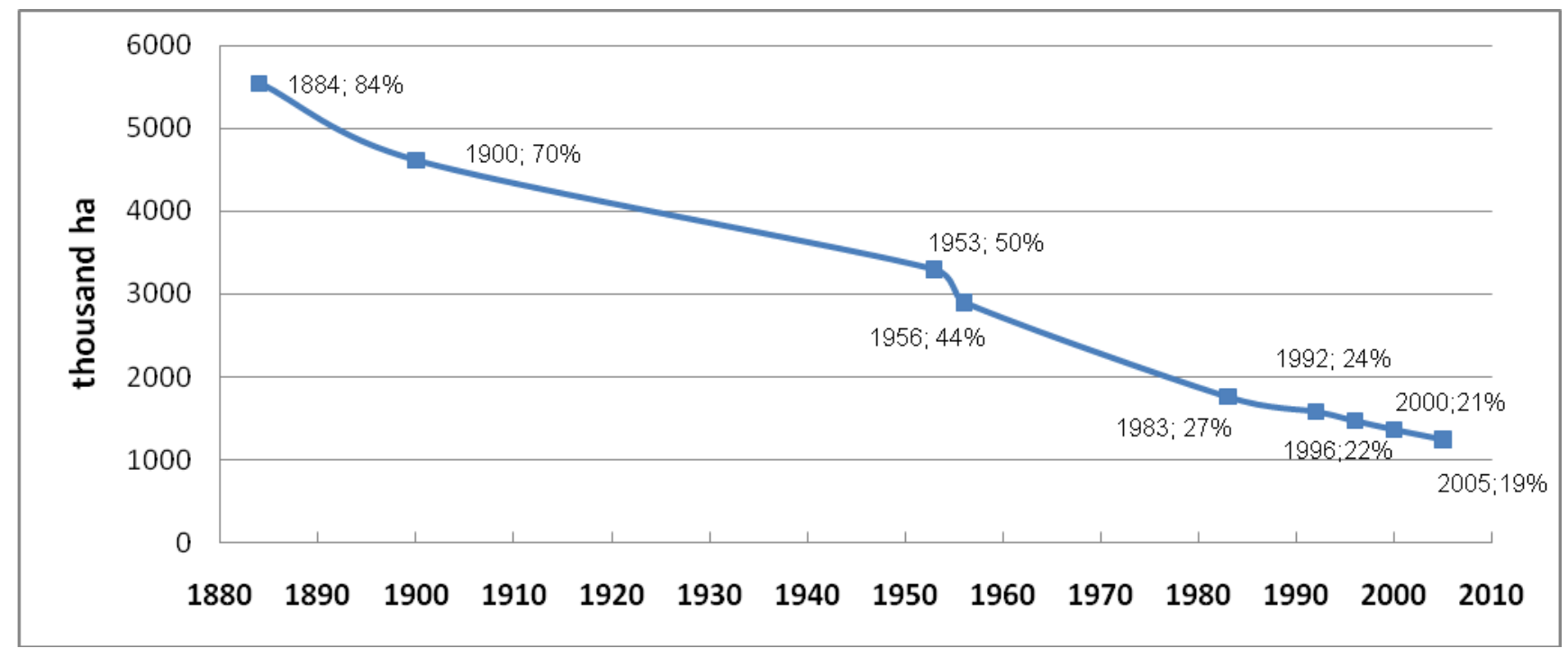

Fig. 2. Decline in forest cover in Sri Lanka, 1884-2005. Note that the table refers to closed-canopy forests only (>70\% crown cover) and excludes open forests and forest plantations. The 2000-2005 figures are based on linear extrapolation from the 1992-1996 values found in FAO (2005), since no national inventories have been conducted since 1996.

The two latest national forest inventories, from Legg and Jewell (1995) conducted in 1992 and GOSL (2000) conducted in 1996, have been used to estimate the forest area needed for reporting to the FAOFRA (FAO, 2010b). These figures will be used in this assessment since these two inventories are the most recent containing district-wise estimates of forest cover. However, we note the fact that a pilot study using 2008 satellite images suggest a drastic reduction in annual deforestation rates - in the order of 50\% — though these results are preliminary (FAO, 2010a).

\subsection{Sri Lankan views of REDD+}

In UNFCCC deliberations, Sri Lanka has been one of the nations supporting the expanded focus of REDD+, highlighting the need to compensate for conservation and sustainable management of forest resources (Sri Lanka, 2008). Sri Lanka also views remote sensing and satellite imaging as appropriate monitoring methodologies, while stressing the lack of resources for implementing such high-tech methodologies. Determining the national reference level requires technological and financial assistance. Sri Lanka also suggests that any future REDD+ mechanism should include a one-time payment for "Baseline Stocks" as an incentive to keep these important sinks intact.

In October 2009, Sri Lanka was granted observer status on the Policy Board of the UN-REDD program (UN-REDD, 2009). This status means they have access to networking and knowledge sharing The UN-REDD program is supporting Sri Lanka with 4 million USD in its initial readiness activities and a REDD+ National Joint Program was set up in 2011 to assist in the development of an effective REDD regime and to contribute to reduction of emissions from deforestation and forest degradation from 2011-2014 (Bandaratillake, 2011). 


\section{Estimating a historical reference level for carbon emissions from deforestation in Sri Lanka}

Above-ground biomass (AGB) was estimated for each tree in 193 single sample plots (each 0.09 ha, i.e., $30 \times 30$ meters, following Ravindranath and Ostwald (2008)) in six natural forest ecosystems in Sri Lanka, in an inventory campaign in 2008 and 2009. Measurements were made in lowland rainforests $(n=96)$, sub-montane forests $(n=10)$, montane forests $(n=24)$, moist monsoon forests $(n$ $=10)$, dry monsoon forests $(n=16)$, and open and sparse forests $(n=36)$. A stratified random sample approach was applied based on the national classification of forest ecosystems defined by precipitation and elevation (Table 1) used in the two latest national forest inventories (Legg and Jewell, 1995; GOSL, 2000). Through visual selection of sample plots, within randomly chosen areas for each ecosystem, all plots were laid in primary and secondary natural forests to capture the variability of status existing under the areas defined as forests. Secondary forests (including open canopy forests) measured in the present study have been subject to human interference in the past but as a result of many years of natural regeneration these forests often resemble primary forest characteristics. Including secondary forests in the analysis also yield a conservative estimate of carbon stock. The sampling size in each forest stratum was calculated based on the suggestions of Penman et al. (2003) using a 10\% level of error and a 95\% confidence level. By applying Winrock Terrestrial Sampling Calculator (Walker et al., 2007), taking into account different variables of each stratum, it was shown that the number of samples were sufficient to reach this precision level for all forest classes except dry monsoon forests. However, due to security reasons tracts of dry monsoon forests in the northern and eastern districts could not be sampled. Consequently, all sample plots were located in the southern and central districts of the country, where all forest categories except mangrove and riverine dry forests were represented. For mangrove forests, we use the AGB estimates of Amarasinghe and Balasubramaniam (1992), and for riverine dry forests, for which no estimates of biomass carbon could be found in the literature, we assumed the same AGB as for dry monsoon forests based on similarity of forest characteristics.

In each sample plot, diameter at breast height $(\mathrm{DBH})(>3 \mathrm{~cm})$, tree height, as well as species or genus information were recorded for each tree. Only above-ground live biomass was measured. Ratios of below-ground biomass to AGB of 0.24 were added for all forest categories except dry monsoon and open forests, which were assigned a ratio of 0.28 (IPCC, 2006, Table 4.4).

Since no allometric relationships could be found for the Sri Lankan context, two allometric models (Winrock and Luckman) developed for tropical forests, including DBH, height, and wood density parameters following Ponce-Hernandez (2004: 19), were first applied to each tree to estimate the AGB. In addition to these two allometric models, we also estimated AGB using a modified tree volume formula to account for tree shape and wood density (Ravindranath and Ostwald, 2008); this formula assumes a constant form factor of 0.648 , which is representative of the tropical broadleaf forests where most of our measurements were made (Chave et al., 2005).

Winrock: $M=\exp ^{\left(-2.409+0.9522 \ln \left(D^{2} \cdot H \cdot S\right)\right)}$

Luckman: $M=0.0899 \cdot\left(D^{2} \cdot H \cdot S\right)^{0.9522}$ 
where $M$ is biomass (in $\mathrm{kg}$ ), $r$ is radius (in $\mathrm{cm}$ ), $D$ is diameter at breast height (in $\mathrm{cm}$ ), $H$ is tree height (in $\mathrm{m}$ ), $S$ is wood density (in $\mathrm{g} \mathrm{cm}^{-3}$ ), and 0.648 is a constant form factor.

To estimate carbon stock, we assumed that carbon accounts for $50 \%$ of dry biomass based on Brown and Lugo (1982) and IPCC (1997). Wood densities for all tree species were taken from Worthington (1959), Reyes et al. (1992), Zanne et al. (2009) and ICRAF (2010), using genus level averages where species specific data was not available (following Chave et al., 2006 and Bryan et al., 2010) and plot level averages for the cases where species could not be identified.

Our measurements were extrapolated up from tree and sample plot scale to hectare scale and subsequently to the national level using the area information for each forest category reported in the two latest national forest inventories (Legg and Jewell, 1995; GOSL, 2000). To estimate the carbon stock values for 2005 and 2010, a historical reference level was constructed by linearly extrapolating the trend from 1992-1996 to 2005, whereas between 2005 and 2010, the district-wise annual deforestation rates were halved, following the latest national estimates reported to the FAO (FAO, 2010a).

\subsection{Results for biomass carbon stocks in Sri Lanka}

In Table 2 we present a Tier 2 estimate of above- and below-ground biomass carbon based on our inventory campaign measurements for eight different natural forest ecosystems according to the national forest classification. Mean biomass carbon stocks range from $29 \mathrm{tC} \mathrm{ha}^{-1}$ for open forest to 218 $\mathrm{tC} \mathrm{ha}^{-1}$ in lowland rainforest. Based on these estimates, we construct a historical baseline for total biomass carbon and average forest carbon content in all Sri Lankan forest categories between 1992 and 2010, (see Table 2 and Fig. 3), presenting the average results of the two allometric equations and the volume formula.

Despite uncertainties in allometric assessments and extrapolation to estimated forest area, the resulting average carbon stock value per hectare from 1992 to 2010 lies within a narrow range of 120-130 tC $\mathrm{ha}^{-1}$ for all forests using all three methods (Table 2). The total carbon loss for Sri Lankan natural forests amounted to $18 \mathrm{MtC}$ between 1992 and 1996. For the 1996-2010 period, the loss was $45 \mathrm{MtC}$, assuming a business-as-usual (BAU) scenario based on the forest cover change rates provided in the two latest FAO assessments (FAO, 2005; FAO, 2010a). In terms of annual emissions from deforestation, this translates to $17 \mathrm{MtCO}_{2} \mathrm{yr}^{-1}$ between 1992 and 1996 and $12 \mathrm{MtCO}_{2} \mathrm{yr}^{-1}$ between 1996 and 2010, which both are around half of the $27.9 \mathrm{MtCO}_{2}$ in total Sri Lankan $\mathrm{CO}_{2}$ emissions from forest and other land-use systems in 1994 (UNFCCC, 2005).

It must be stressed that the error range and uncertainty for estimating a historical reference level are high for several reasons. First, the two forest inventories from 1992 and 1996 use two different inventory designs including area estimates that are not clearly comparable. Second, the error range includes natural variations depending regionally on tree species composition, forest disturbance, temperature, precipitation, elevation, and soil fertility. Third, more sample plots in dry monsoon forests would be needed to reach the desired precision level. The literature also indicates that the choice of allometric equation can result in errors exceeding $20 \%$ of above-ground biomass and even more when large trees are abundant (Chave et al., 2004; Kirby and Potvin, 2007). 
Table 2. Carbon stock estimates in above- and below-ground biomass carbon showing total (MtC), per hectare $\left(\mathrm{tC} \mathrm{ha}^{-1}\right)$, forested area (1000 ha) and range $\left(\mathrm{tC} / \mathrm{ha}^{-1}\right)$ of different Sri Lankan forest ecosystems from 1992 to 2010 using Tier 2 data from our inventory campaign and forested area estimates from earlier inventories. Tier 1 estimates of above- and below-ground biomass carbon applied to Sri Lankan and Asian forests are shown from several sources.

Tier 2 estimates - inventory campaign

2008-2009

\begin{tabular}{|c|c|c|c|c|c|c|c|c|c|c|c|c|c|}
\hline \multirow{2}{*}{$\begin{array}{c}\text { Forest } \\
\text { ecosystem }\end{array}$} & \multicolumn{3}{|c|}{1992} & \multicolumn{3}{|c|}{1996} & \multicolumn{3}{|c|}{2005} & \multicolumn{3}{|c|}{2010} & \multirow{2}{*}{$\begin{array}{c}\text { range } \\
\left(\mathrm{tC} \mathrm{ha}^{-1}\right)\end{array}$} \\
\hline & \multicolumn{2}{|c|}{ MtC } & Ha & \multicolumn{2}{|c|}{ MtC } & Ha & MtC & \multicolumn{2}{|c|}{ Ha } & MtC & \multicolumn{2}{|c|}{ Ha } & \\
\hline Lowland rainf. & \multicolumn{2}{|c|}{31} & 142 & \multicolumn{2}{|l|}{27} & 124 & 20 & \multicolumn{2}{|c|}{93} & 19 & \multicolumn{2}{|c|}{86} & $203-225$ \\
\hline Sub-montane & \multicolumn{2}{|c|}{12} & 69 & \multicolumn{2}{|l|}{11} & 66 & 10 & \multicolumn{2}{|c|}{59} & 10 & \multicolumn{2}{|c|}{58} & $159-172$ \\
\hline Montane & \multicolumn{2}{|c|}{0.1} & 3 & \multicolumn{2}{|l|}{0.1} & 3 & 0.1 & \multicolumn{2}{|c|}{3} & 0.1 & \multicolumn{2}{|c|}{3} & $43-50$ \\
\hline Moist monsoon & \multicolumn{2}{|c|}{33} & 244 & \multicolumn{2}{|l|}{30} & 222 & 24 & \multicolumn{2}{|c|}{180} & 23 & \multicolumn{2}{|c|}{170} & $125-139$ \\
\hline Dry monsoon & \multicolumn{2}{|c|}{173} & 1094 & \multicolumn{2}{|l|}{163} & 1028 & 141 & \multicolumn{2}{|c|}{892} & 136 & & & $153-162$ \\
\hline Open forests & 13 & & 464 & 14 & & 72 & 14 & & 9 & 14 & & & $26-31$ \\
\hline Mangrove & 0.7 & & 9 & 0.8 & & 10 & 1.0 & & 2 & 1.1 & & & $35-149$ \\
\hline Riverine & 4 & & 23 & 3 & & 18 & 2 & & 2 & 1 & & & $153-162$ \\
\hline & MtC & tC ha ${ }^{-1}$ & Ha & MtC & tC ha ${ }^{-1}$ & Ha & MtC & tC ha ${ }^{-1}$ & Ha & MtC & tC ha ${ }^{-1}$ & $\mathrm{Ha}$ & \\
\hline 10 & 267 & 130 & 2048 & 249 & 128 & 1943 & 210 & 122 & 1740 & 204 & 120 & 1698 & $120-150$ \\
\hline
\end{tabular}

Tier 1 estimates - Sri Lanka

\begin{tabular}{|c|c|c|c|c|c|c|c|c|c|c|c|c|c|}
\hline \multirow{2}{*}{ Source } & \multicolumn{3}{|c|}{1990} & \multicolumn{3}{|c|}{2000} & \multicolumn{3}{|c|}{2005} & \multicolumn{3}{|c|}{2010} & \multirow{2}{*}{$\begin{array}{c}\text { range } \\
\left(\mathrm{tC} \mathrm{ha}{ }^{-1}\right)\end{array}$} \\
\hline & MtC & tC ha $^{-1}$ & $\mathrm{Ha}^{1}$ & MtC & tC ha ${ }^{-1}$ & $\mathrm{Ha}^{1}$ & MtC & $\mathrm{tC} \mathrm{ha}^{-1}$ & $\mathrm{Ha}^{1}$ & MtC & tC ha ${ }^{-1}$ & $\mathrm{Ha}^{1}$ & \\
\hline FAO (2005) & 53 & 23 & 2350 & 45 & 22 & 2082 & 40 & 21 & 1933 & N/A & N/A & N/A & $21-33$ \\
\hline FAO (2010a) & 90 & 38 & 2350 & 74 & 36 & 2082 & 66 & 34 & 1933 & 61 & 33 & 1860 & $33-38$ \\
\hline Gibbs et al. (2007) & & & & $\begin{array}{c}138- \\
509\end{array}$ & 158 & 2082 & & & & & & & $66-244$ \\
\hline $\begin{array}{c}\text { Brown (1997); } \\
\text { FAO/UNDP } \\
(1969)\end{array}$ & & & & & & & & & & & & & $153-290$ \\
\hline
\end{tabular}

\begin{tabular}{c|ccc}
$\begin{array}{c}\text { Tier } 1 \text { estimates -Asian specific } \\
\text { Source }\end{array}$ & & $\begin{array}{c}\text { range } \\
\left(\mathbf{t C} \text { ha }^{-\mathbf{1}}\right)\end{array}$ \\
\hline IPCC (2006) & & $30-210$ \\
\hline $\begin{array}{c}\text { Achard et al. } \\
(2004)\end{array}$ & & $121-181$ \\
\hline Houghton (1999) & & $150-290$ \\
\hline Brown (1997) & & $46-164^{2}$
\end{tabular}

${ }^{1}$ Forest areas here also include forest plantations.

${ }^{2}$ Combined estimated range for continental and insular tropical Asia.

\subsection{Comparison with other forest biomass carbon data}

Table 2 also compares our results with those of four other surveys, which should be regarded as Tier 1 information estimates of biomass carbon specifically for Sri Lankan forests. All surveys indicate larger variations in carbon content than those arrived at here; however-except for national forest cover and total forest ecosystem carbon figures reported to FAO-FRA, which are well below most other estimates - our results are within the range of previous estimates. 


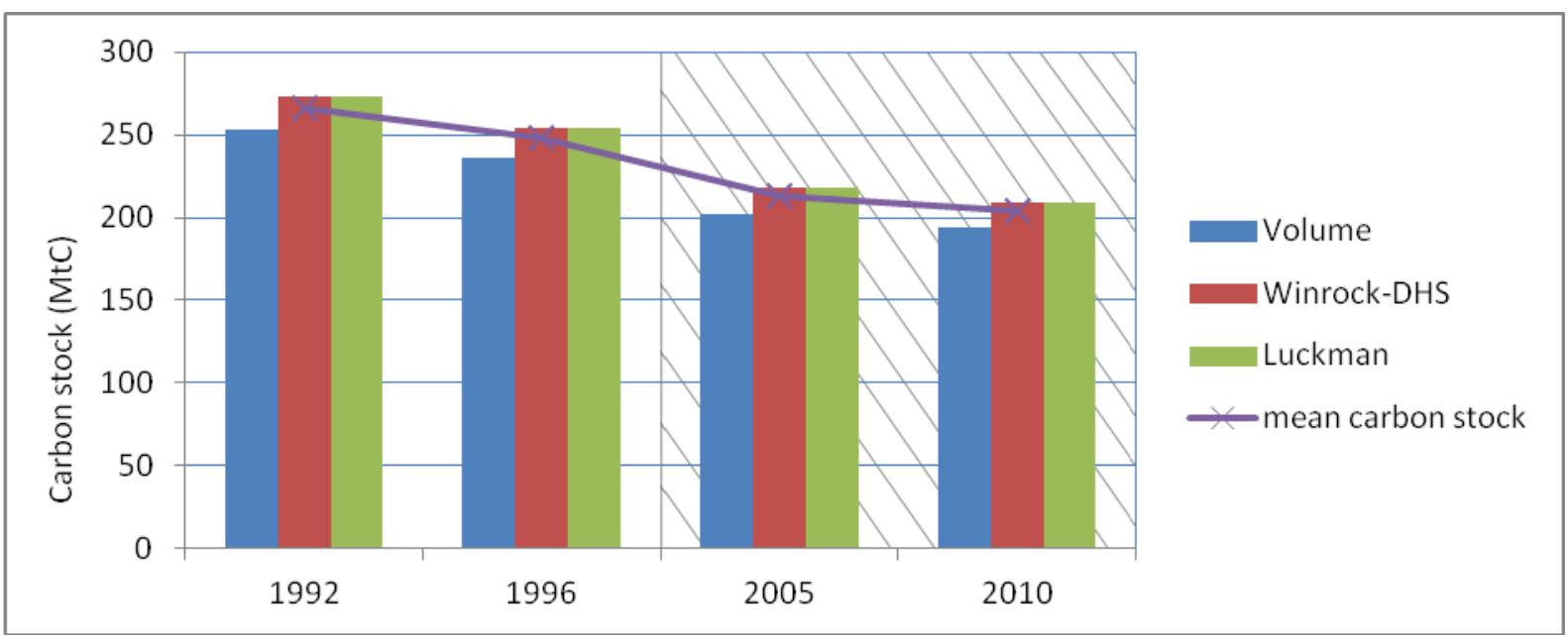

Fig. 3. Historical reference level for 1992-2010, obtained via linear extrapolation and assuming a business-as-usual scenario for 2005 and a 50\% decline in 2010 of the 1992-1996-2005 trend, hence the striped background. Total gross biomass carbon stocks for Sri Lankan natural forests 1992-19962005-2010 are shown for the three methods used.

Gibbs et al. (2007) estimate the total forest carbon stock for Sri Lanka by applying biome-average forest carbon values (compilations of several sources published from 1983 to 2007) to a satellite-based global land-cover map for the year 2000 stratified by the FAO forest ecological zone map, resulting in Tier 1 estimates. By dividing the total carbon stock by total forest area, we arrive at an average carbon density estimate in the range of 66-244 $\mathrm{tC} \mathrm{ha}^{-1}$ using original figures by Gibbs et al. (2007). Brown (1997) reports figures originally published by FAO/UNDP (1969) of 153-290 tC ha ${ }^{-1}$. Measurements were originally made in evergreen (i.e., high-, medium-, low-yield, and logged) forests and secondary forests in Sri Lanka, a different classification system from the national forest classification system used in our biomass carbon assessment.

For the Asian region as a whole, combined above and below-ground carbon values range from 30 to $210 \mathrm{tC} \mathrm{ha}^{-1}$ according to IPCC (2006), very much in line with the range from open forests to lowland rainforests reported here. These estimates are derived from the above-ground biomass dry matter of forests from various ecological zones in Asia. Achard et al. (2004) use a mean above- and belowground biomass value of $151 \mathrm{tC} \mathrm{ha}^{-1}$ based on Brown (1997). Houghton (1999) estimates a figure of $150 \mathrm{tC} \mathrm{ha}^{-1}$ to $250 \mathrm{tC} \mathrm{ha}{ }^{-1}$ over a longer time period from 1850 to 1990 , while Brown (1997) estimates values of $46 \mathrm{tC} \mathrm{ha}^{-1}$ and $135 \mathrm{tC} \mathrm{ha}^{-1}$ for lowland and montane forests of continental tropical Asia, respectively, and $104 \mathrm{tC} \mathrm{ha}^{-1}$ and $164 \mathrm{tC} \mathrm{ha}^{-1}$ for montane and lowland forests of insular tropical Asia, respectively. Notably, the IPCC (2006) range for the whole Asian region is smaller than the reported carbon stock estimates for Sri Lanka alone.

\section{Estimating the costs and benefits to Sri Lanka of participating in REDD+}

We estimate the cost of reducing the future GHG emissions from deforestation in Sri Lanka to assess the possible benefit to Sri Lanka of participating in REDD+. Two main determinants of the cost are the drivers of deforestation - determining the opportunity cost of forest conservation - and the carbon content of the forest. Given the considerable variability in forest carbon densities in Sri Lanka, the fact that the causes of deforestation vary widely across both time and space (White, 2006), and that 
detailed accounts of deforestation processes in Sri Lanka — especially for recent years-are scarce, estimating the cost of reducing deforestation in Sri Lanka is very challenging.

\subsection{Identifying the drivers of deforestation}

A combination of qualitative and quantitative data (Table 3) was used to attribute the clearing of Sri Lankan forests in 1992-1996 to a limited set of proximate drivers and to estimate the opportunity cost of conservation. The qualitative data come from the scientific literature, mainly White (2006) and UNEP (2001), on the proximate causes of deforestation in the various districts and agro-ecological zones of Sri Lanka. Quantitative data on annual changes in the area of land in paddy (rainfed and irrigated) and tea in the period for which we have detailed data on deforestation rates, 1992-1996 (Table 3), were gathered. By combining this with the qualitative data on how drivers of deforestation vary across ecological zones and forest types, we constructed the following rules for apportioning the deforestation in each district to either rice or tea cultivation, prawn farming, or rainfed agriculture (in Sri Lanka commonly denoted chena):

(1) in each district where there was a net increase in rice paddy (asweddumized ${ }^{4}$ ) area, this was assumed to be associated with any clearing of dry monsoon, dry riverine, and moist monsoon forests in the district;

(2) in each district where there was an net increase in the extent of tea cultivation, this was assumed to be associated primarily with any clearing of lowland rainforest, and secondarily of montane and sub-montane forest in the district;

(3) in coastal districts where there was a net clearing of mangrove forest from 1992 to 1996, we assumed that this was due to the expansion of prawn farms; and

(4) the balance of forest clearing in each district was assumed to be due to rainfed agriculture.

Following this, we estimated that of the total clearing of approximately $28,800 \mathrm{ha} \mathrm{yr}^{-1}$ from 1992 to $1996,87 \%$ was due to rainfed agriculture, $7 \%$ to rice cultivation, $6 \%$ to tea cultivation, and $0.2 \%$ to prawn farming (Table 3). To summarize, rice cultivation has encroached on forest mainly through large-scale irrigation and settlement schemes in the dry zone and cash crops through the expansion of smallholder tea in lowland rainforests. Rainfed agriculture has driven deforestation in all agroecological zones, though it is most prevalent in the dry lowland zone of the southeast and north, where approximately $80 \%$ of the population is dependent on rainfed farming for subsistence.

\subsection{Results for the opportunity cost of forest conservation}

The opportunity cost of forest conservation is calculated as the net present value (NPV) for each land use replacing forests, assuming a constant stream of future revenues and a discount rate of $10 \%$. The latter is in line with most other estimates of REDD opportunity costs in the literature (e.g., Grieg-Gran 2008).

\footnotetext{
${ }^{4}$ Asweddumized land denotes land prepared for rice cultivation. As such, change in asweddumized extent is a better proxy for land use change due to rice cultivation than areas sown or harvested, as these will vary from year to year due to economic and climatic factors.
} 
Table 3. Gross deforestation in the 1992-1996 period, annual changes in the cultivated extent of rice paddy (asweddumized land) (1992-1996), tea (1992-2002), agro-ecological zones, and the assumed allocation of deforestation among drivers for each district. Chena denotes rainfed agriculture.

\begin{tabular}{|c|c|c|c|c|c|c|c|c|c|c|}
\hline \multirow[b]{2}{*}{ District: } & \multirow{2}{*}{$\begin{array}{l}\text { Deforest } \\
\text {-ation, } \\
1992- \\
1996^{\mathrm{a}} \\
\left(\text { ha yr }^{-1}\right)\end{array}$} & \multicolumn{4}{|c|}{ Rice paddy extent ${ }^{b}$} & \multicolumn{5}{|c|}{$\begin{array}{c}\text { Assigned drivers: share of gross } \\
\text { deforestation in } \%\end{array}$} \\
\hline & & $\begin{array}{l}\text { Irrigated } \\
\left(\mathrm{ha} \mathrm{yr}^{-1}\right)\end{array}$ & 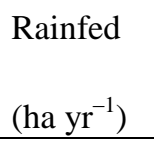 & 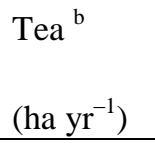 & $\begin{array}{l}\text { Main agro-- } \\
\text { ecological } \\
\text { zones }^{c}\end{array}$ & $\begin{array}{l}\stackrel{\mathscr{\Xi}}{:} \\
\dot{\Xi}\end{array}$ & 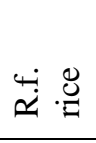 & $\underset{\frac{\pi}{2}}{\tilde{U}}$ & $\stackrel{\mathscr{\Theta}}{\oplus}$ & 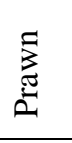 \\
\hline Ampara & 436 & 292 & 56 & & Dl & 56 & 11 & 33 & - & - \\
\hline Anuradhapura & 3802 & -167 & 0 & & D1 & - & - & 100 & - & - \\
\hline Badulla & 919 & 97 & 46 & 221 & $\mathrm{Il} / \mathrm{Im} / \mathrm{Iu}$ & 10 & 5 & 62 & 23 & - \\
\hline Batticaloa & 382 & 59 & -48 & & Dl & - & - & 100 & - & - \\
\hline Colombo & 118 & 24 & -2 & 12 & W1 & - & - & 90 & 10 & - \\
\hline Galle & 34 & 0 & 24 & 278 & Wl & - & - & - & 39 & 61 \\
\hline Gampaha & 13 & 4 & 33 & & Wl & - & - & 100 & - & - \\
\hline Hambantota & 295 & 3 & 7 & 12 & $\mathrm{Dl} / \mathrm{Il}$ & - & - & 95 & 1 & 4 \\
\hline Jaffna & 11 & 0 & -64 & & Dl & - & - & 62 & - & 38 \\
\hline Kalutara & 1572 & 4 & 8 & 341 & Wl & - & - & 77 & 22 & 1 \\
\hline Kandy & 16 & 67 & -11 & -346 & $\mathrm{Wm} / \mathrm{Im}$ & - & - & 100 & - & - \\
\hline Kegalle & 428 & 0 & 1 & 82 & Wl & - & - & 82 & 18 & - \\
\hline Kilinochchi & 28 & 22 & 0 & & Dl & 39 & - & 61 & - & - \\
\hline Kurunegala & 614 & 195 & 362 & -10 & $\mathrm{Il} / \mathrm{Dl}$ & 32 & 59 & 9 & - & - \\
\hline Mannar & 1626 & 0 & 0 & & Dl & - & - & 100 & - & - \\
\hline Matale & 4571 & 17 & 49 & 98 & $\mathrm{Im} / \mathrm{Il} / \mathrm{Iu}$ & 0.4 & 1 & 96 & 2 & - \\
\hline Matara & 358 & 26 & -71 & 262 & $\mathrm{Wl}$ & - & - & 33 & 67 & 0.3 \\
\hline Moneragala & 4993 & 20 & 21 & 36 & $\mathrm{Dl} / \mathrm{Il}$ & 0.4 & 0.4 & 98 & 1 & - \\
\hline Mullativu & 1270 & 0 & 0 & & $\mathrm{D} 1$ & - & - & 99 & - & 1 \\
\hline Nuwaraeliya & 1141 & 8 & 1 & -199 & $\mathrm{Wu}$ & 1 & - & 99 & - & - \\
\hline Polonnaruwa & 385 & 758 & -20 & & Dl & 100 & - & - & - & - \\
\hline Puttalam & 3362 & 193 & 29 & & $\mathrm{Dl} / \mathrm{Il}$ & 6 & 1 & 93 & - & - \\
\hline Ratnapura & 858 & 216 & 19 & 994 & $\mathrm{Wm} / \mathrm{Il} / \mathrm{Dl}$ & 20 & 2 & 27 & 51 & - \\
\hline Trincomalee & 378 & 0 & 0 & & $\mathrm{Dl}$ & - & - & 100 & - & - \\
\hline Vavuniya & 425 & -6 & -1 & & D1 & - & - & 100 & - & - \\
\hline
\end{tabular}

${ }^{\mathrm{a}}$ From Legg and Jewell (1995) and GOSL (2000).

${ }^{\mathrm{b}}$ Agriculture and Environment Statistics Division (2010).

${ }^{\mathrm{c}} \mathrm{D}=$ dry, $\mathrm{I}=$ intermediate, $\mathrm{W}=$ wet, $\mathrm{l}=$ lowland, $\mathrm{m}=$ mid-elevation, $\mathrm{u}=$ upland.

Reported net revenues from small-scale, rainfed agriculture are in the range of USD 120-700 $\mathrm{ha}^{-1} \mathrm{yr}^{-1}$ depending on location, crops cultivated, and farming practices (Bogahawatte, 1999; Illukpitiya, 2005; Molle and Renwick, 2005; Premakantha, pers. comm., 2010; Socio-Economics and Planning Centre, 2010). Here NPV of rainfed agriculture of USD $1400 \mathrm{ha}^{-1}$ and USD $5000 \mathrm{ha}^{-1}$ in the dry/intermediate and wet zones, respectively, are assumed. The former stems from an assumed income of USD $300 \mathrm{ha}^{-1}$ $\mathrm{yr}^{-1}$ and a rotation period of three years of cultivation followed by a five-year fallow, while the latter assumes a USD $600 \mathrm{ha}^{-1} \mathrm{yr}^{-1}$ net income and a four plus one year cultivation-fallow rotation.

However, assigning a single opportunity cost of avoided forest clearing for rainfed agriculture must be viewed with some caution, as rainfed agriculture represents a wide range of agricultural practices in terms of inputs, yields, and fallow requirements. It should be noted that rainfed agriculture is far from being only a subsistence activity; rainfed agriculture farming today often involves hired labor, cultivation of a wide variety of crops, responsiveness to market signals, and incomes that may be as high as those of settlers in large-scale paddy irrigation schemes (Peiris, 2006). 
For rainfed and irrigated rice cultivation, official statistics on net revenues across districts are used (Socio-Economics and Planning Centre of the Department of Agriculture, 2010). ${ }^{5}$ For those districts for which no net revenue data are available, average Sri Lankan net revenues per kg of rice multiplied by district-averaged yields per hectare are used (Agriculture and Environment Statistics Division, 2010). The resulting land rents vary between USD 300 and USD $840 \mathrm{ha}^{-1} \mathrm{yr}^{-1}$ under rainfed conditions and between USD 650 and USD $1450 \mathrm{ha}^{-1} \mathrm{yr}^{-1}$ under irrigated conditions, depending mainly on district-specific yields.

For tea cultivation, we assume a land rent of USD $530 \mathrm{ha}^{-1} \mathrm{yr}^{-1}$, representing an average between the figures of Peiris (2006) and Sri Lanka Equity Analytics (2010). For prawn farming, we assume a land rent of USD 13,600 ha $\mathrm{yr}^{-1}$, following Rohitha (2008).

In addition to agricultural incomes, foregone timber revenues constitute an opportunity cost of forest conservation. Little information is available on the extent to which timber is harvested before preparing land for agriculture in Sri Lanka and on associated timber revenues (Premakantha, pers. comm., 2010). Here, net timber revenues are assumed to range from just over USD 11,000 ha ${ }^{-1}$ in lowland rainforests to just under USD $1900 \mathrm{ha}^{-1}$ in dry monsoon and riverine forest (and zero in montane and mangrove forests), based on average harvested wood volumes across forest types from Sri Lanka Forestry Sector Master Plan (MFE, 1995; cited in Gunatilake and Gunaratne, 2002), a roundwood price in the lower end of the range for various species of plantation wood (Premakantha, pers. comm., 2010), and harvest and transport costs amounting to $10 \%$ of the timber value (Gunatilake and Gunaratne, 2002). However, these estimates should be viewed as highly speculative.

We do not account for incomes from produce charcoal from mangrove wood (though this does not affect the results, since the opportunity cost of mangrove conservation is already very high). Nor do we assume any forgone income from non-timber forest products (NTFPs) as forest is cleared (i.e., the only revenue from forest conservation is that from REDD+-credits), since data on the utilization of this resource is scarce and in any case these revenues - though not insignificant (Bogahawatte, 1999) — are small compared to those from agriculture or potential REDD+ incomes.

Fig. 4 presents the marginal cost of reducing deforestation in Sri Lanka, based on the assumed drivers of deforestation across districts and forest types, the associated biomass carbon contents, and the opportunity costs of conservation presented above, with and without the highly uncertain timber revenues. The inclusion of timber revenues roughly doubles the opportunity costs of reducing deforestation, so it is obviously an important factor to study in greater depth.

In addition to the opportunity cost of forest conservation, the real cost of reducing deforestation will also depend on (1) transaction costs arising from negotiating, designing, implementing, monitoring, and enforcing national REDD+ policies, and (2) downstream economic value added from the land uses replacing forests (Ghazoul et al., 2010). While the administrative costs associated with policy implementation are in most cases not prohibitive (Wertz-Kanounikoff, 2008), the costs arising from policy imperfections (e.g., non-additionality and leakage) can be substantial (Blackman, 2010; Fisher et al., 2011). For example, the real cost of forest conservation in for example payments for environmental services (PES) or protected areas (PA) systems may be many times higher than the cost

\footnotetext{
${ }^{5}$ The estimates of net revenues include the implicit cost of own farm labor. In the case of high unemployment rates, this may overestimate the opportunity cost of own labor, so the present estimates could be seen as conservative. Annual net revenues are calculated assuming that district-wise net revenues per $\mathrm{kg}$ of rice produced in each of the two growing periods (maha and yala) are equal.
} 
per hectare due to the fact that a large share of payments or land conserved where not threatened by clearing (Blackman, 2010). Similarly, Fisher et al. (2011) show that implementation cost of REDD+ in Tanzania - through increased agricultural yields and charcoal production efficiency — exceed opportunity costs of forest conservation.

Transaction costs are notoriously difficult to assess (especially ex-ante) and will in the end depend on the policies chosen to implement REDD+ nationally. However, the fact that most of the emission reductions will need to come from a myriad of small farmers, practicing small-scale, rainfed agriculture, indicates that transaction costs in Sri Lanka could be relatively high. We therefore chose to test the sensitivity of Sri Lankan revenues from REDD+ to the level of transaction costs in a wide range, raising opportunity costs between zero and $200 \%$.

Finally, estimates of the opportunity cost of forest conservation as this here underestimates the true costs due to the omission of value added in downstream economic activities (e.g., revenue and employment in food processing and service industries) (Ghazoul et al., 2010). In the analysis presented here these costs are most likely small, however, as over $90 \%$ of the estimated revenues from REDD+ are due to reduction in clearing for rainfed farming for subsistence or local markets where there is no downstream processing industries. The social cost of restricting land use options for these farmers may however be far from negligible, as in some areas of Sri Lanka approximately $80 \%$ of the population is dependent on rainfed farming for subsistence. This needs to be reflected in national REDD+ policies if they are to be politically and socially tenable, as well as effective.

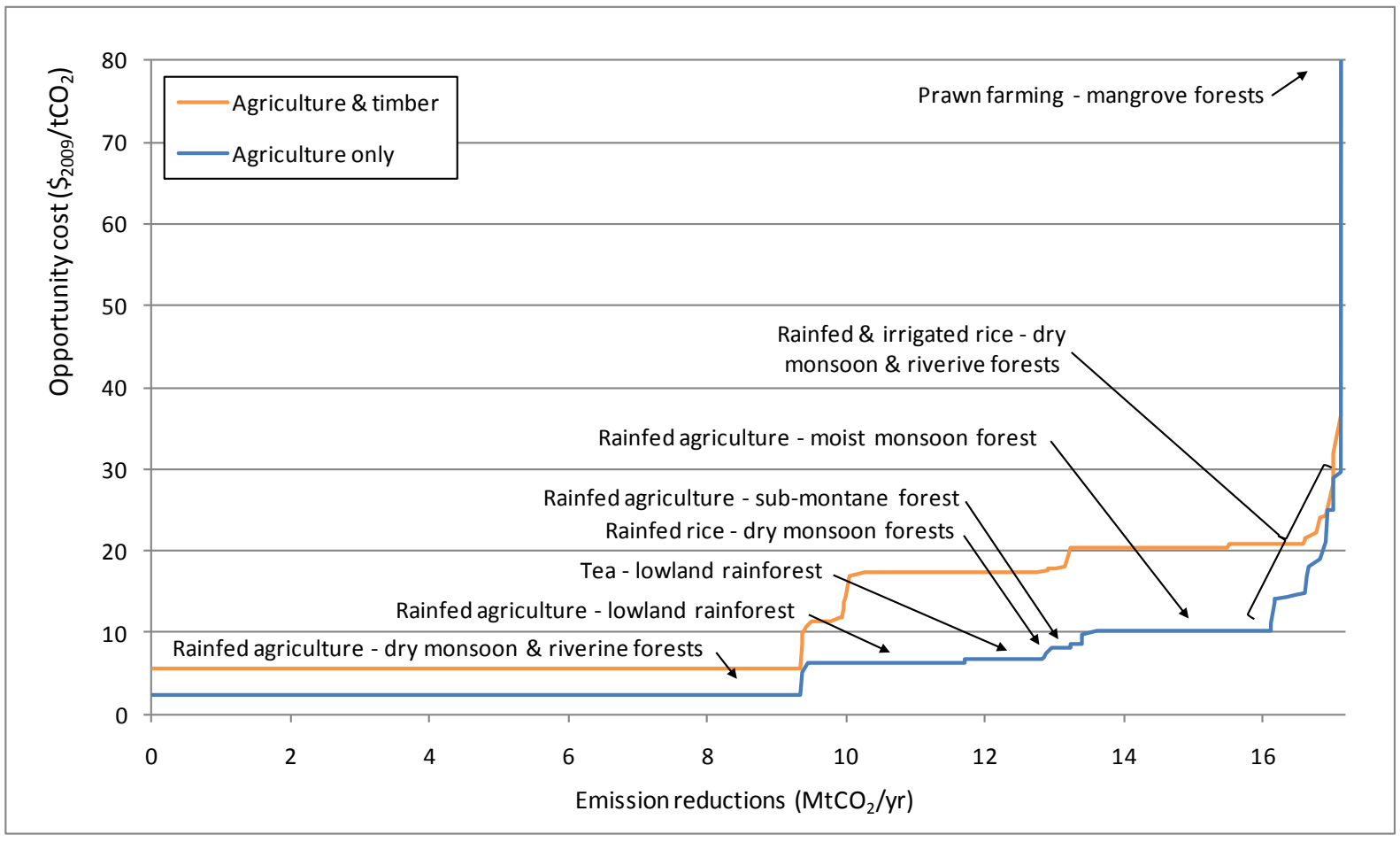

Fig. 4. The estimated marginal abatement cost (MAC) curve for reducing $\mathrm{CO}_{2}$ emissions from deforestation in Sri Lanka, based on historical (1992-1996) data on deforestation rates across districts and forest types, estimates of biomass carbon contents of various forest types and net revenues from the displayed drivers of deforestation. 


\subsection{Potential revenue from forest conservation}

Figure 5 displays how the revenues to Sri Lanka from participating in REDD+, and associated reductions in annual carbon emissions from deforestation, depend on three key variables: (1) the carbon price on avoided emissions, (2) whether timber revenues are realized or not, and (3) the level of the costs for implementing conservation policies and actually realizing REDD+. Potential annual revenues span a wide range, from zero to over USD 400 million. In the latter case, gross revenues would equal roughly $10 \%$ of Sri Lanka's annual export earnings (CIA, 2010) - a not insubstantial increase in national income.

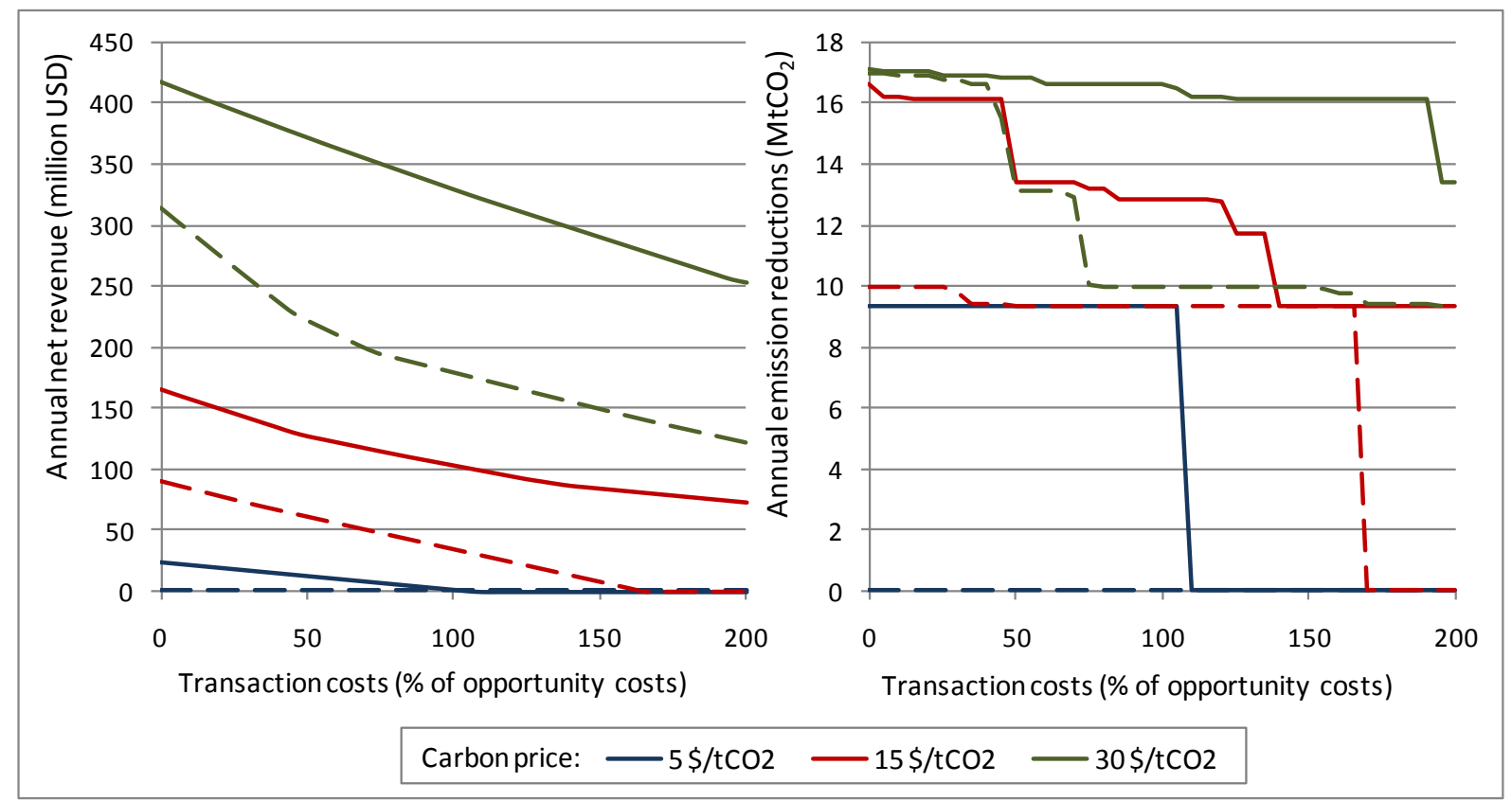

Fig. 5. Potential revenues to Sri Lanka from REDD+ (left) and associated emission reductions (right), for different levels of carbon payments, different levels of transaction costs, and for the cases when timber revenues in connection with deforestation are either excluded (continuous lines) or included (dashed lines).

As can be seen in Figure 5, revenues and emission reductions are highly dependent on the level of the compensation for reduced emissions. At a carbon price of USD 5/ $\mathrm{tCO}_{2}$ - the current price for forestry offsets in the voluntary market (Diaz et al., 2011), as well as the price stipulated in the bilateral REDD+ agreement between the governments of Guyana and Norway (Guyana and Norway, 2009) and in the Brazilian Amazon Fund (MMA, 2008) — net revenues are close to or at zero, especially if implementation costs or timber revenues are not negligible. Thus, a realistic estimate of the potential revenues is most likely in the lower end of the range presented here and, most importantly, it takes a higher carbon price than what is currently used in many REDD+ pilot projects to make it worth for Sri Lanka to participate in a REDD+ regime at all.

The costs associated with implementing REDD+ in Sri Lanka of course affects the resulting revenues, though not to the same extent as the carbon price; as long as the carbon price is higher than $\$ 10 / \mathrm{tCO}_{2}$ Sri Lanka will have a strong economic incentive to participate in a REDD+ regime, even if implementation costs triple the total cost of emission reductions. Similarly, the level of timber revenues associated with deforestation in Sri Lanka has a large, but not critical, impact on economic incentives for participation in REDD+. 
Note, finally, that the cost of reducing deforestation in Sri Lanka and associated estimated gains from REDD+ participation are based on deforestation rates and drivers prevailing in the 1992-1996 period. If the lower deforestation rate recently reported to FAO-FRA (FAO, 2010a) is reflected in the REDD+ reference level, Sri Lanka would stand to gain less from participating in a REDD+ scheme, since fewer possible reductions in deforestation are left to be compensated for. This is especially the case if the remaining deforestation is mainly due to highly profitable agriculture ${ }^{6}$ (i.e., the right half of the MAC displayed in Fig. 4), reducing net revenues by 55-90\% (the lower the carbon price, the higher the decrease in revenues).

\section{Discussion}

This study is a first step to address carbon stock variations, drivers, costs, earnings and knowledge gaps that need to be filled in order to achieve REDD+ readiness in Sri Lanka, a country so far lacking such an assessment. Our analysis show that using empirically based, nationally derived data on forest carbon stocks can substantially reduce uncertainties compared to preexisting Tier 1 estimates.

Still, while the present analysis has substantially reduced the uncertainty around average carbon stocks in different forest ecosystems, Sri Lanka currently have difficulties producing a robust Tier 2 reference level for deforestation (even more so for degradation, carbon enhancement and reforestation) due to lack of consistent and repeated national inventories of the extent of forest cover. Our estimated reference level have taken into account the new national forest area estimates reported to FAO-FRA in 2010 (FAO, 2010a), indicating a 50\% decline in the rate of forest cover loss since 2005. However, this data is not based on new national inventories but is solely a trend based on secondary reports, consultancy reports, and pilot studies using satellite imaging in 2008 (FAO, 2010a).

In order to produce a robust reference level for Sri Lanka it is thus imperative to carry out new analyses of the extent and changes in forest area, using recent and historic data on forest cover and forest cover change that is consistent. This calls for technical advice, training, and capacity building to develop and use high-tech methods, such as satellite remote sensing, in Sri Lanka, underpinned by financial support, something that have been stressed by Sri Lanka in the latest UNFCCC submission on the issue (Sri Lanka, 2008). Local expertise also needs to be used to account for national circumstances and validate the outcomes of methodological assessments. Measuring forest degradation is secondary; it would require more resources and technical expertise and could be implemented using existing and evolving remote sensing technologies.

Our analysis of the cost of reducing deforestation in Sri Lanka indicated relatively low costs for reducing the bulk of the emissions and potentially large gains for Sri Lanka from REDD+ participation. However, uncertainties abound and one should not confuse the possibly low cost of reducing emissions from deforestation and forest degradation with the ease of doing so. The success of REDD+ in arresting deforestation and forest degradation will in the end depend on the policies adopted nationally to implement REDD+ and finding effective policy responses will require a more profound understanding of the primary and underlying drivers of deforestation on a sub-national scale. Also, as already noted, estimated revenues from REDD+ are most likely in the lower end of the

\footnotetext{
${ }^{6}$ One piece of evidence pointing in this direction would be that rice paddy (asweddumized) extent increased

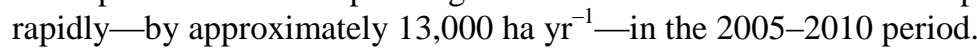


presented range since implementation costs and timber revenues are likely to increase the cost of reduced deforestation and current carbon prices for REDD+ projects and agreements are very low.

Recent successful attempts to reduce deforestation rates through governmental interventions in Sri Lanka have been observed (Lindström, 2011) and drawing lessons from these experiences may help inform REDD+ policies. Where forest protection was most effective, it was coupled with migration from forest dense areas, due to urbanization and increases in off-farm employment — but also with negative livelihood impacts the remaining households who saw their access to forest resources being prohibited (Lindström, 2011). The former gives some indication of the occurrence of a forest transition (Mather, 2007) in Sri Lanka, where declining population growth rate along with increased economic development are contributing to a decline in deforestation rates (this is also in line with trends presented in Ratnayake et al. (2002) and Gunawardane et al. (2010)). This also means that part of the policies needed to realize REDD+ may lie outside the agriculture and forestry sector (i.e., increasing the pull factors in the forest transition).

The reported negative livelihood impacts from forest protection initiatives also point to hard trade-offs and the need to balance development and environmental aspirations. The fact that our economic analysis shows that the major share $(>90 \%)$ of potential emission reduction comes from decreases in the expansion of small-scale, rain-fed agriculture, clearly underscores this point. Formulating effective and equitable REDD+ policies therefore needs to be an inclusive process, involving local stakeholders (e.g., through community forestry management), and in the end some of the mitigation options identified as low cost here-i.e., reducing clearing for subsistence farming - may be less desirable than some identified as high cost-i.e., reduced clearing of mangroves for shrimp farming, which increases the economic vulnerability of coastal societies (Mattsson et al., 2009).

Though our analysis show that the opportunity cost of REDD+ is relatively low in Sri Lanka today, in the longer run REDD+ will also have to compete with an increasing global demand for agricultural land, induced by population increase, rising incomes, and climate-policy-driven demand for bioenergy. The effect of this became evident during the recent world food price spike, with, e.g., revenues from rice cultivation roughly tripling between 2001 and 2009 (Peiris, 2006; SocioEconomics and Planning Centre, 2009). If food prices and biofuel demand continue to rise, REDD+ may find it increasingly difficult to compete with alternative uses of good agricultural land and the REDD+ policies formulated today need to be resilient to such changes in the incentives for agricultural expansion (Persson, 2011).

Since 2008, Sri Lanka has been actively engaged in the international REDD+ discussions and is currently in a dynamic process where issues relating to natural resource management is promoted within ministries, organizations and academia. The National Joint Program initiated in 2011 within the UN-REDD National Program seeks to establish a forest inventory program in the country. This will include reviewing available methodologies and developing methodologies combining satellite imagery and field sampling of natural forests, forest plantations and other tree resources (Bandaratillake, 2011; Chokkalingam and Vanniarachchy, 2011). This information can facilitate detailed follow up studies on this topic in a few years time as more consistent data will become available to allow more accurate estimates on Tier 3 level to estimate reference levels and the associated costs and earnings for REDD+ in Sri Lanka. 
Finally, this assessment considers only deforestation, excluding the "+" in REDD+. Further assessments, including of carbon enhancement, conservation, and sustainable management of forests are matters for future research.

\section{Conclusions}

The following conclusions can be drawn from our analysis:

- According to our in situ estimates (Tier 2), the forest, above and below ground, in Sri Lanka holds an average carbon stock of $120-130 \mathrm{tC} \mathrm{ha}^{-1}$, substantially reducing the uncertainty span from earlier Tier 1 assessments.

- Still, there is a large range in carbon stock $\left(26-225 \mathrm{tC} \mathrm{ha}^{-1}\right)$ between forest types, due to the heterogeneity of forest ecosystems as well as different forest usage in the recent past causing variations in successions.

- Reference level development in Sri Lanka is hampered by erratic, few, and often incompatible forest inventories that lower the potential to describe forest carbon content in a creditable way.

- The potential monetary gains to Sri Lanka from participating in REDD+ could be considerable, but it requires carbon compensation levels to exceed those currently applied in REDD+ pilot projects and agreements (i.e., $>5 \$ / \mathrm{tCO} 2$ ) and that implementation costs are kept low through effective REDD+ policies. The latter requires a deeper understanding of the various drivers of deforestation and forest degradation in Sri Lanka.

- A major share (>90\%) of the potential emission reductions under REDD+ comes at the expense of small-scale, rain-fed agriculture, which raises concerns about the livelihood impacts of REDD+ interventions in Sri Lanka. The implementation of REDD+ policies need to be sensitive to these concerns if they are to be effective and equitable.

- Apart from sustaining strong political will, for Sri Lanka to achieve readiness to participate in REDD+, the nation needs assistance in the form of technical advice, training, and capacitybuilding for monitoring the nation's forest resource (highlighted in the National Communication to UNFCCC) and the drivers of deforestation. The process also likely includes synergies with other national development and environmental goals.

\section{Acknowledgements}

The authors acknowledge the Swedish Energy Agency, the Swedish International Development and Cooperation Agency, and Göteborg Energi for their financial support. We would also like to thank our colleagues in Sri Lanka for their field assistance and input, particularly S. Bandaranayake, D.P. Kumaratunge, P.S. Pathinayake, A.C. Dissanayaka, and K.T. Premakantha as well as the Department of Crop Science at the University of Peradeniya, Sri Lanka. We would further like to thank Frédéric Achard, Hans-Jürgen Stibig, and the Environment Unit at the Joint Research Centre in Ispra, Italy. Thanks must also be extended to Göran Wallin, Sabine Henders and Elisabeth Simelton and our colleagues at the Forest Initiative for Climate and Livelihood (FOCALI) research network 
(www.focali.se) for their productive comments. We also thank the anonymous reviewers for their helpful comments.

\section{References}

Achard, F., Eva, H.D., Mayaux, P., Stibig, H.-J., Belward, A., 2004. Improved estimates of net carbon emissions from land cover change in the tropics for the 1990s. Glob. Biogeochem. Cycles 18 GB2008 doi:10.1029/2003GB002142

Agriculture and Environment Statistics Division (AESD), 2010. Department of Census and Statistics, Colombo, Sri Lanka. Statistics online, available at http://www.statistics.gov.lk/agriculture/index.htm (retrieved 2010-10-01)

Amarasinghe, M.D., Balasubramaniam, S., 1992. Net primary productivity of two mangrove forest stands on the northwest coast of Sri Lanka. Hydrobiologia 247, 37-47.

Angelsen, A., Brown, S., Loisel, C., Peskett, L., Streck, C., Zarin, D., 2009. Reducing Emissions from Deforestation and Forest Degradation (REDD): An Options Assessment Report. Meridian Institute, Washington, DC.

Bandaratillake, H.M., Sarath Fernando, M.P., 2003. National forest policy review: Sri Lanka. In Enters, T., Qiang, M., Leslie, R.N. (Eds.), An Overview of Forest Policies in Asia. FAO, Bangkok.

Bandaratillake, H.M., 2011. UN-REDD National Programme Document Sri Lanka - Draft

Blackman, A., 2010. Will REDD really be cheap? Resources 174(Winter/Spring):4

Bogahawatte, C., 1999. Forestry Policy, Non-Timber Forest Products and the Rural Economy in the Wet Zone Forests in Sri Lanka. Department of Agricultural Economics, University of Peradeniya, Sri Lanka \& Economy and Environment Program for Southeast Asia. EEPSEA, Singapore.

Brown, S., Lugo, A.E., 1982. The storage and production of organic matter in tropical forests and their role in the global carbon cycle. Biotropica 14, 161-187.

Brown, S., 1997. Estimating Biomass and Biomass Change of Tropical Forests, FAO Forestry Paper 134, 55 pp. FAO, Rome.

Bryan J.E., Shearman P.L., Ash J., Kirkpatrick J.B., 2010. Estimating rainforest biomass stocks and carbon loss from deforestation and degradation in Papua New Guinea 1972-2002: best estimates, uncertainties and research needs. Journal of Environmental Management. 91, 995-1001.

Chave, J., Condit, R., Aguilar, S., Hernandez, A., Lao, S., Perez, R., 2004. Error propagation and scaling for tropical forest biomass estimates. Philosophical Transactions of the Royal Society of London Series B-Biological Sciences 359, 409-420.

Chave, J., Andalo, C., Brown, S., Cairns, M.A., Chambers, J.Q., Eamus, D., Folster, H., Fromard, F., Higuchi, N., Kira, T., Lescure, J.P., Nelson, B.W., Ogawa, H., Puig, H.,Riera, B., Yamakura, T., 2005. 
Tree allometry and improved estimation of carbon stocks and balance in tropical forests. Oecologia $145,87-89$.

Chave, J., Muller-Landau, H.C., Baker, T.R., Easdale, T.A., Ter Steege, H., Webb, C.O., 2006.

Regional and phylogenetic variation of wood density across 2456 neotropical tree species. Ecological Applications 16, 2356-2367.

Chokkalingam, U., Vanniarachchy, S.A., 2011. Sri Lanka's REDD Potential: Myth or Reality? Forest Carbon Asia Country Profile Report No. 1: Sri Lanka. Forest Carbon Asia. Available at: http://www.forestcarbonasia.org/wp-content/uploads/2010/10/Sri-Lanka-Country-Report-final23.05.2011.pdf (retrieved 2011-12-06)

CIA (Central Intelligence Agency), 2010. The World Factbook. Available at https://www.cia.gov/library/publications/the-world-factbook/geos/ce.html (retrieved 2010-11-16)

CAIT (Climate Analysis Indicators Tool), 2010. Version 8.0. Washington, DC: World Resources Institute.

Department of Agriculture, 2010. Climate of rice growing regions in Sri Lanka. Available at http://www.agridept.gov.lk/pagelinks.php?pagelink=Climate\%20of\%20rice\%20growing\%20regions\% 20in\%20Sri\%20Lanka\&heading=Rice (retrieved 2010-06-01)

Department of Census and Statistics, 2010. Population and housing. Available at http://www.statistics.gov.lk/PopHouSat/Mid\%20Year\%20Population/Table\%201.pdf (retrieved 2010$10-01)$

Diaz, D., Hamilton, K.., Johnson, E., 2011. State of the Forest Carbon Markets 2011: From Canopy to Currency. Ecosystem Marketplace/Forest Trends. Available at http://www.foresttrends.org/documents/files/doc_2963.pdf (retrieved 2011-09-17)

FAO, 1997. Asia-Pacific Forestry Sector Outlook Study: Country Report—Sri Lanka. Colombo: FAO. FAO, 2005. Global Forest Resources Assessment, Country Reports-Sri Lanka. FRA2005/123, Rome, 2005.

FAO, 2010a. Global Forest Resources Assessment, Country Reports—Sri Lanka. FRA2010/197, Rome, 2010.

FAO, 2010b. Global Forest Resources Assessment 2010, main report. Available at http://foris.fao.org/static/data/fra2010/FRA2010_Report_1oct2010.pdf (retrieved 2010-11-17)

FAO/UNDP, 1969. Pre-investment study on forest industries development. Ceylon, Final Report, Vol. II. Forest resources and management. FAO/SF: 60/CEY-5, Rome, Italy.

Fisher, B., S.L. Lewis, N.D. Burgess, R.E. Malimbwi, P.K. Munishi, R.D. Swetnam, R. Kerry Turner, S. Willcock., Balmford, A., 2011. Implementation and opportunity costs of reducing deforestation and forest degradation in Tanzania. Nature Clim. Change 1 (3):161-164. 
Ghazoul, J., Butler, R.A., Mateo-Vega, J., Koh, L.P., 2010. REDD: A reckoning of environment and development implications. Trends Ecol Evol, 10.1016/j.tree.2010.03.005.

Gibbs, H.K., Brown, S., Niles, J.O., Foley, J.A., 2007. Monitoring and estimating tropical forest carbon stocks: Making REDD a reality. Environmental Research Letter doi:10.1088/17489326/2/4/045023

GOSL, 2000. Forest Cover Mapping 2000. Forest Inventory Division. Forest Department. Sri Lanka Government of Sri Lanka, 2000. Initial national communication under the United Nations framework convention on climate change. Colombo.

Government of Sri Lanka, 2000. Initial National Communication under the United Nations Framework Convention on Climate Change. Colombo, Sri Lanka.

Grieg-Gran, M., 2008. The Cost of Avoiding Deforestation: Update of the Report prepared for the Stern Review of the Economics of Climate Change. International Institute for Environment and Development (IIED), London, UK.

Griscom, B., Shoch, D., Stanley, B., Cortez, R., Virgilio, N., 2009. Sensitivity of amounts and distribution of tropical forest carbon credits depending on baseline rules. Environmental Science and Policy 12:897-911

Gunatilake, H. M., 1998. The role of rural development in protecting tropical rainforests: evidence from Sri Lanka. Journal of Environmental Management, 53(3), 273-292.

Gunatilake, H.M., Gunaratne, L.H.P., 2002. Policy Options for Conserving Sri Lanka's Natural Forests. Economy and Environment Program for Southeast Asia (EEPSEA) Research Report rr2002061. Available at http://ideas.repec.org/p/eep/report/rr2002061.html

Gunawardane, H.G., Silva, A., Kulathunga, R.S., Weragoda, A.C., Edirisinghe, N., Manikkawasagam, T., Panduka., Chandrani, R.P.D.S., Boralassa, T.N.S., Yogaratnam, K. 2010. Forest Cover Assessment and Identification of Forests and other Ecological Sensitive Areas for Conservation. Integrated Strategic Environmental Assessment Project, Northern Province. Prepared for: Forest Department, Ministry of Environment and Natural Resources. Available at: http://www.isea.lk/dl_gal/207/252.pdf (retrieved 2011-12-06)

Guyana and Norway, 2009. Memorandum of Understanding between the Government of the Cooperative Republic of Guyana and the Government of the Kingdom of Norway regarding Cooperation on Issues related to the Fight against Climate Change, the Protection of Biodiversity and the Enhancement of Sustainable Development. Available at: http://www.regjeringen.no/upload/MD/Vedlegg/Internasjonalt/miljosamarbeid_utviklingsland/mou_no rway_guyana.pdf. (retrieved 2011-09-17)

Houghton, R. A., 1999. The annual net flux of carbon to the atmosphere from changes in land use 1850-1990 Tellus B 51:298-13.

ICRAF, 2010. World Agroforestry Wood Density Database. Available at: http://www.worldagroforestry.org/Sea/Products/AFDbases/wd/ (retrieved 2010-05-24) 
Illukpitiya, P., 2005. Technical efficiency in agriculture and dependency on forest resources: an economic analysis of rural households and the conservation of natural forests in Sri Lanka. EEPSEA Technical Report.

IPCC, 1997. Revised 1996 IPCC guidelines for national greenhouse gas inventories, report, World Meteorol. Org. Geneva.

IPCC, 2006. 2006 IPCC Guidelines for national Greenhouse Gas Inventory, prepared by the National Greenhouse Gas Inventory Programme, Eggleston H.S., Buendia L., Miwa K., Ngara T. and Tanabe K. (eds). Published: IGES, Japan

Kirby, K.R., Potvin, C., 2007. Variation in carbon storage among tree species: implications for the management of a small-scale carbon sink project. For. Ecol. Manage. 246, 208-221.

Legg, C., Jewell, N., 1995. A 1.50,000 forest map of Sri Lanka: the basis for a National Forest Geographic Information System. Special Issue, The Forester, Forestry Information Service (eds.). The Sri Lanka Forest Department, Battaramulla, Sri Lanka.

Lindström, S., 2011. Tropical deforestation in Sri Lanka - a minor field study investigating the impact of small scale farmers. University of Gothenburg, Sweden. Available at: http://www.focali.se/filer/Uppsats_Tropical\%20deforestation\%20in\%20Sri\%20Lanka_final1 109091.pdf (retrieved 2011-12-06)

Mather, A. S., 2007. Recent Asian forest transitions in relation to forest transition theory. International Forestry Review 9(1): 491-502.

Mattsson, E., Ostwald, M., Nissanka, S.P., Holmer, B., and Palm M., 2009. Recovery and protection of coastal ecosystems after tsunami event and potential for participatory forestry CDM-examples from Sri Lanka. Ocean and Coastal Management 52:1-9

MFE, 1995. Sri Lanka Forestry Sector Master Plan. Forestry Planning Unit, Ministry of Forestry and Environment (MFE), Sri Lanka.

Miles, L. 2007. Reducing Emissions from Deforestation: Global Mechanisms, Conservation and Livelihoods. UNEP-WCMC, Cambridge. Available at http://www.unepwcmc.org/medialibrary/2010/09/24/b47912fd/Miles_2007_REDD.pdf (retrieved 2011-08-02)

Ministério do Meio Ambiente (MMA) 2008. Project Document - Amazon Fund. Ministério do Meio Ambiente, Brasilia, Brazil. Available at:http://www.amazonfund.gov.br/FundoAmazonia/export/sites/default/site_en/Galerias/Arquivos/Bol etins/Amazon_Fund_-_Project_Document_Vs_18-11-2008.pdf (retrieved 2011-09-17)

Molle, F. and Renwick, M., 2005. Economics and Politics of Water Resources Development: Uda Walawe Irrigation Project, Sri Lanka. IWMI Research Report 87. IWMI, Colombo, Sri Lanka. 
Mollicone, D., Achard, F., Federici,. S., Eva, HD., Grassi, G., Belward, A., et al. 2007. An incentive mechanism for reducing emissions from conversion of intact and non-intact forests. Climatic Change 83: 477-493.

Nanayakkara, V.R., 1996. Forests and Forestry in Sri Lanka: an historical perspective. Commonwealth Secretariat.

Penman, J., Gytarsky, M., Hiraishi, T., Krug, T., Kruger, D., Pipatti, R., Buendia, L., Miwa K., Ngara, T., Tanabe, K., and F. Wagner (2003). Good Proctice Guidance for Land Use, land-use change and forestry. IGES for IPCC.

Peiris, G.H., 2006. Sri Lanka: Challenges of the New Millennium. Kandy Books, Colombo, Sri Lanka.

Persson, U.M., 2011. Conserve or covert? Pan-tropical modeling of REDD-bioenergy competition. Biological Conservation, in press. doi:10.1016/j.biocon.2011.10.038

Ponce-Hernandez, R., 2004. Assessing Carbon Stocks and Modelling Win-win Scenarios of Carbon Sequestration through Land-use Changes, Food and Agriculture Organization of the United Nations, Rome, Italy (2004).

Premakantha, K.T., 2010. Personal communication. Divisional Forest Officer, Kurunegala district, Sri Lanka. Email correspondence 14 July 2010.

Ratnayake, J., Abeykoon, M., Chemin, Y., 2002. District-wise forest area variation in Sri Lanka from 1992 to 2001 for supporting the National Physical Planning Policy. Available at: http://www.a-a-rs.org/acrs/proceeding/ACRS2002/Papers/FR02-3.pdf (retrieved 2010-12-06)

Ravindranath, N.H., Ostwald, M., 2008. Carbon Inventory methods-Handbook for greenhouse gas inventory, carbon mitigation and roundwood production projects. Advances in Global Change Research Volume 29. Springer Verlag.

Reyes, G., Brown, S., Chapman, J., and Lugo A.E., 1992. Wood densities of tropical tree species. General Technical Report SO-88. USDA Forest Service, Southern Forest Experiment Station, New Orleans, Louisiana, USA.

Rohitha, W.R., 2008. Evaluating gains from de-eutrophication of the dutch canal in Sri Lanka: a cost benefit analysis. Working paper No. 29-08, South Asian Network for Development and Environmental Economics (SANDEE), Kathmandu, Nepal.

Socio-Economics and Planning Centre, 2010. Cost of cultivation of agricultural crops: 2008/09 Maha. Agricultural Economic Study No. 87, Department of Agriculture, Peradeniya, Sri Lanka.

Sri Lanka, 2008. Paper no 11: Sri Lanka, Item 14. Reducing Emission from Deforestation in Developing Countries: Approaches to stimulate Action. Submissions from Parties to SBSTA $28^{\text {th }}$ session Bonn, 4-13 June 2008.

Sri Lanka Equity Analytics 2010. Sri Lanka: Plantation sector report. Available at http://www.srilankaequity.com/2010/02/sri-lanka-plantation-sector-report.html (retrieved 2010-03-01) 
Suthakar, K., Bui, E.N., 2008. Land use/cover changes in the war-ravaged Jaffna Peninsula, Sri Lanka, 1984-early 2004. Singapore Journal of Tropical Geography, 29: 205-220. doi: 10.1111/j.1467-

9493.2008.00329.x

Strassburg, B., Turner R.K,. Fisher B,. Schaeffer R, and. Lovett A., 2009. Reducing emissions from deforestation-The "combined incentives" mechanism and empirical simulations. Global Environmental Change. 19(2):265-278.

UNEP, 2001. Sri Lanka: State of the Environment 2001. Nairobi, Kenya. Available at http://www.rrcap.unep.org/pub/soe/srilankasoe.cfm. (retrieved 2010-03-01)

UNFCCC, 2005. National communications from parties not included in Annex I to the Convention Compilation and synthesis of initial national communications. FCCC/SBI/2005/18/Add.2

UNFCCC, 2009. Methodological guidance for activities relating to reducing emissions from deforestation and forest degradation and the role of conservation, sustainable management of forests and enhancement of forest carbon stocks in developing countries. FCCC/CP/2009/11/Add.1

UNFCCC, 2010. Outcome of the work of the Ad Hoc Working Group on long-term Cooperative Action under the Convention. Draft decision -/CP.16.

UNFCCC, 2011. Expert Meeting on "Forest reference emission levels and forest reference levels for implementation of REDD-plus activities” Bonn, Germany 14 - 15 November, 2011. Co-chairs' summary.

UNFCCC, 2011. Draft decision on guidance on systems for providing information on how safeguards are addressed and respected and modalities relating to forest reference emission levels and forest reference levels as referred to in decision 1/CP.16, appendix I. Draft decision -/CP.17

UN-REDD, 2009. Report of the Third Policy Board Meeting Washington D.C. US 29-30 October 2009.

Walker, S.M., Pearson, T., Brown, S., 2007. Winrock Terrestrial Sampling Calculator. Bio Carbon Fund, Winrock International.

Wertz-Kanounnikoff, S., 2008. Estimating the cost of reducing forest emissions: A review of methods. Working Paper No. 42, Center for International Forestry Research (CIFOR), Bogor, Indonesia.

White, R., 2006. Macroeconomic policy framework for reducing deforestation. Tufts University, USA. Available at http://fletcher.tufts.edu/research/2006/White.pdf (retrieved 2010-03-01)

Worthington, T.B,, 1959. Ceylon Trees. The Colombo Apothecaries’ Company Ltd, Colombo.

Zanne, A.E., Lopez-Gonzalez, G., Coomes, D.A., Ilic, J., Jansen, S., Lewis, S.L., Miller, R.B., Swenson, N.G., Wiemann, M.C., and Chave, J., 2009. Global wood density database. Dryad. Identifier: http://hdl.handle.net/10255/dryad.235. (retrieved 2010-10-04) 
